\title{
Perception of Undergraduate Accounting Students towards Professional Accounting Career in Nigeria
}

\author{
Ben-Caleb. E ${ }^{1}$, Ademola, A. $\mathrm{O}^{2}$, Adegboyegun, A. $\mathrm{E}^{3}$, Olowookere, J. $\mathrm{K}^{4}$ \& Oladipo, O. A ${ }^{1}$ \\ ${ }^{1}$ Dept. of Accounting and Finance, Landmark University, Omu-Aran, Kwara State, Nigeria \\ ${ }^{2}$ Dept. of Banking and Finance, Osun State University, Osun State, Nigeria \\ ${ }^{3}$ Dept. of Accounting, Adekunle Ajasin University, Akungba Akoko, Ondo State, Nigeria \\ ${ }^{4}$ Dept. of Accounting, Osun State University, Osun State, Nigeria \\ Correspondence: Ademola, A. O, Dept. of Banking and Finance, Osun State University, Osun State, Nigeria.
}

Received: July 2, 2020

Accepted: December 24, 2020

Online Published: December 28, 2020

doi:10.5430/ijhe.v10n3p107

URL: https://doi.org/10.5430/ijhe.v10n3p107

\begin{abstract}
The shortage of professional accountants has been attributed to the perception accounting students hold about their intended professional careers and this affects their self-image, attitude towards the career and their confidence in the profession. Therefore, this paper critically appraises the perception of undergraduate accounting students towards professional accounting career in Nigeria. One hundred and fifty (150) accounting students from three universities in Nigeria participated in this study and data were elicited from the respondents with the aid of well-structured questionnaires. Descriptive Statistics and Spearman Rank Correlation Coefficient were used for data analysis.

Findings showed that students are motivated to pursue professional accounting career by combination of prestige, extrinsic and intrinsic factors. Furthermore, results indicated that grit personality, prestige, extrinsic and intrinsic factors exhibited strong and positive correlation with student's intention to pursue accounting career. However, social and reference factors displayed positive but weak correlation. Additionally, students perceive professional examinations to be very tough, expensive, time-consuming and frightening. Thus, they refrain from writing professional examinations and that could be detrimental to the future of professional accounting career in Nigeria. Therefore, this research suggests that educational institutions, accounting professional bodies and career counselors play their roles to inspire, support and motivate accounting students to work towards professionalism.
\end{abstract}

Keywords: accounting, professional qualification, extrinsic factors, grit personality

\section{Introduction}

Professional services contribute significantly to the gross domestic product and employment of any nation. Among the most important and powerful professions in modern day calculative economy and society is Accounting. Accounting is basically an indispensable profession in contemporary economy and society at large. It shapes how organizations are governed and decisions are made in both private and public sectors. Accountants perform essential duties in major organizations and their decisions have significant and far-reaching financial and social implications. Owing to the significant position occupied by accounting profession in the Nigerian economy, enrollment of students in accounting continues to increase day by day in Nigerian tertiary institutions.

However, despite the significant interest in this profession, only just few accounting graduates are pursuing professional qualifications in Nigeria. This is confirmed by the low percentage of professional accountants registered with ICAN and ANAN. For instance, ICAN which is Africa's largest professional organization represents only 50000 chartered accountants in Nigeria (Chartered Accountants Worldwide, 2019). To further buttress this assertion, Emeyonu (2007) reported that the rate of production and educational development of accountants in Nigeria is very slow in comparison with developed nations. The shortage of professional accountants has significance for the profession and public because professional associations are to certify that accountants are highly knowledgeable and skillful to safeguard public interest (Johnson, 2003). This certification acts as a quality assurance tool for employers during employment and promotion of accountants (Snyder, 2004).

However, the short supply of professional accountants has been attributed to the perception accounting students hold about their intended professional careers in accounting which affect their self-image, attitude towards the career and 
even their confidence in the profession (Dalci, Arasli, Tümer, \& Baradarani, 2013). Germanou et al., (2009) further asserted that a student would pursue professional accounting career, if he or she perceives accounting profession positively. Wrong perceptions generate inaccurate representations; therefore, it becomes crucial for accounting students to have a reasonable perception of what the accounting profession involves (Byrne \& Willis, 2005).

Furthermore, perception of accounting by the society influences whether brilliant or intelligent students will be attracted to the profession or not". Marriott \& Marriott (2003) asserted that parochial nature of accountants and other wrong perception some students have about the accounting profession may likely account for the general decrease in the number of students aspiring to become professional accountants.

In the United State of America, Albrecht and Sack (2000) highlighted five factors that may likely account for the general decrease in the number of students aspiring to become professional accountants: They are low starting salaries, availability of other fascinating career choices, eagerness to select risky majors, a misinterpretation of accountants and the accounting profession and the specification of the 150-hour rule. Three of the five highlighted factors justify how students perceive accounting profession.

Moreover, Lanson (2010) posited that just two to four percent of accounting graduates pursue professional qualification. The researcher further buttressed this assertion that the number of accounting graduates who fail to pursue professional qualification is increasingly alarming and has become worrisome. The significant marginalization of Nigerians in the accounting profession has raised anxiety amongst various stakeholders and as such the reasons for the shortage should be explored. The shortage of accountants thus necessitates accelerating the training of more accountants. In this regard, it becomes pertinent to investigate the perception of accounting students towards professional accounting career in Nigeria. Therefore, this study seeks:

- To examine the salient factors influencing student's choice of accounting career

- To determine the relationship between factors influencing student's career choice and student's intention to pursue accounting career

- To ascertain the perception of accounting students towards professional examination in Nigeria

\section{Literature Review}

\subsection{Empirical Studies on Perception of Accounting Students towards Accounting Profession}

Perception of accounting profession is an underlying factor in determining accounting student's intention in the pursuit of professional career. Prior researches discovered that some students recognised accountants as trustworthy and respectable people due to the requirements of the profession (Germanou, Hassall, \&Tournas, 2009). Hartwell $e t$ al., (2005) revealed affirmatively that students are of the belief that accounting degree would be beneficial to people who desire a career that is challenging. Sugahara \& Boland (2006) discovered that Japanese accounting students are more favorably disposed towards their proposed profession compared to those of non-accounting business students. Also, Sugahara \& Boland (2006) indicated that professional accountants are notable persons who can impact significantly on accounting students career choice.

In contrast, Coate et al., 2003 investigated students' perceptions of the accounting profession and discovered that the nature of accounting work, work environment and absence of ingenuity influenced to a great extent student's decision not to pursue professional qualification. Wessels \& Steenkamp (2009) further asserted that some accountants who are dishonest, untruthful, shrewd in financial reporting and often conceal vital materials in financial reports discourage students from pursuing their professional qualifications.

Moreover, previous studies confirmed that people perceived accountants as individuals who are highly organised and rigidly adhere to regulatory specifications (Parker, 2000; Hunt et al., 2004). Chen, et al., (2008) also discovered that students opined that accounting work is accurate and meticulous, forestalling interest and inhibiting creativity. Byrne and Willis (2005) buttressed this assertion that student's perceived accounting career as uninteresting, explicit and compliance-driven. This could be attributed to prevarication or lack of orientation about the roles played by accountants (Abrecht\& Sack, 2000)

Although, professional accounting bodies are trying hard to erase the erroneous impression that students have about accounting; howbeit, it has yielded little or no results (Jackling \& Calero, 2006). Byrne \& Willis (2005) maintained that the negative perception that people have towards accountants might restrain students from pursuing professional qualification. 


\subsubsection{Factors Influencing Student's Pursuit of Professional Accounting Career in Nigeria}

Intrinsic and extrinsic motives play significant roles as factors influencing student's pursuit of professional accounting career. Byrne \& Flood (2005) and Arquero et al., (2009) opined that extrinsic factors such as good salary, security of job and employment opportunities influenced student's pursuit of professional qualifications. Meanwhile, the researchers further asserted that intrinsic factors such as job specialization, job flexibility and job accomplishment makes students to be favorably disposed towards professional accounting career.

Moreover, the research conducted by Jackling et al., (2012) on Australian and international students showed that for both groups, prestige factor constitutes a significant driving force that motivates them to pursue accounting profession. This report tallies with the findings of Germanou and Hasall (2009) that prestige factor remains the predominant force that propels accounting students in their quest for professionalism.

Furthermore, grit which means strong resolution and passion for long term goals form a prevalent factor that influence student's perception towards professional career. Bacanli (2006) stressed that personality characteristics impacts significantly on career indecisiveness. Gunkel, Schlaegel, Langella and Peluchette (2010) also opined that personality traits directly affect choice of student's career. Duckworth and Peterson (2007) buttressed this assertion that grit personality is one of the prominent qualities that influence student's perception towards professional qualifications.

Social factor is also a significant factor affecting student's pursuit of accounting career which shows clearly the perception of the society towards accounting profession. Byrne et al., (2012), and Wells and Fieger, (2005) found that social status has a significant negative effect on students' pursuit of accounting career. The society viewed accounting as a profession with lesser social significance, having relatively easy entry specifications. They are of the opinion that accounting profession provides less challenging and less interesting career. They suggested that students with excellent communication skills would likely fit in perfectly to better professions other than accounting.

Furthermore, the significance of reference factors in student's pursuit of accounting profession cannot be overestimated. Pimpa (2007) confirmed that reference group such as parents, parents' occupation, instructors in high school and friends influence student's choice of career. However, Hardin et al., (2000) asserted that some teachers and instructors have inadequate information about accounting and therefore find it difficult to guide the students through. The attributes, descriptions and categories of each factor are outlined in Table 1.

Table 1. Attributes, description, and categories of factors influencing student's choice of career

\begin{tabular}{ccc}
\hline Attributes & Description & Category \\
\hline Economic benefits & Large salary and other financial rewards from one's career & Extrinsic \\
Job security & Keeping one's job for a long period of time & Extrinsic \\
Work condition & Suitable physical environment & Extrinsic \\
Advancement & Having promotion as at when due & Prestige \\
Decision making & Being part of decision makers & Prestige \\
Social status & Being recognized in the society as a result of your profession & Prestige \\
Nature of the job & The profession may be interesting or boring & Intrinsic \\
Personal growth & The job allows for learning new things & Intrinsic \\
Achievement & New things are accomplishable easily with my profession & Intrinsic \\
Autonomy & Highly independent and free from imposed constraints in the work place & Intrinsic \\
Self esteem & I feel elated and fulfilled as a professional & Intrinsic \\
Contributionto society & I am able to contribute positively to the society & Social \\
Working with others & I can get along with other people and make friends easily & Social \\
\hline
\end{tabular}




\subsection{Theoretical Framework}

\subsubsection{The Theory of Reasoned Action}

This theory was invented by Ajzen and Fishbein in the early 1980s. It states that a person's behavior is a function of:

a) The individuals' attitude toward the behavior and

b) His/her perception of social pressure to manifest that behavior

Attitude refers to the assumption that behavior will generate certain reactions and social pressure is the presumption that particular individuals or groups accept or reject the behavior

In relation to this study, this theory measures the perception of students towards professional accounting career in Nigeria.

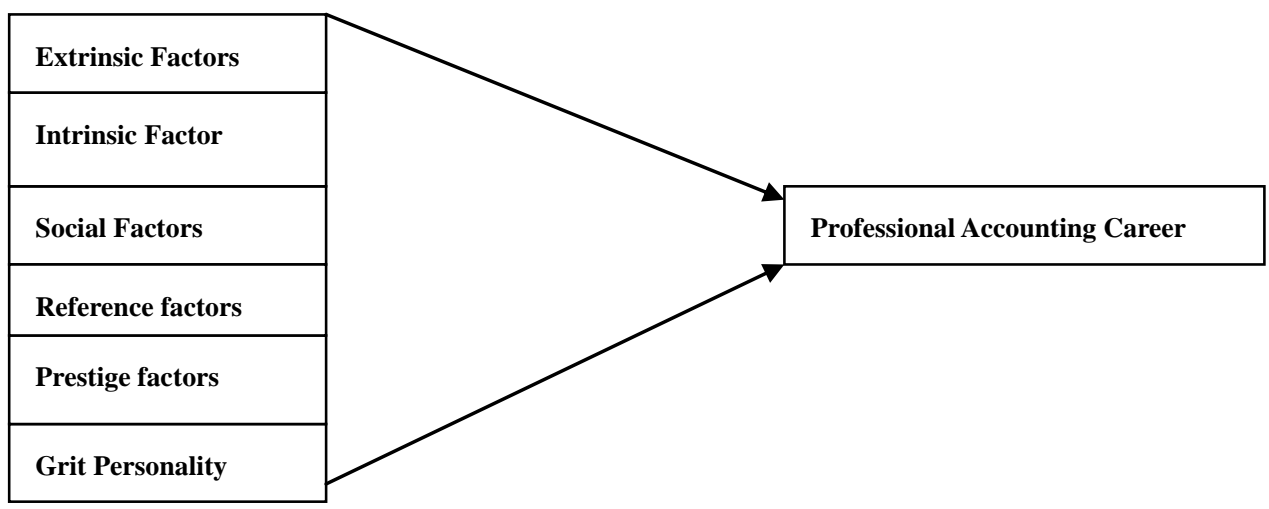

Figure1. Conceptual framework showing factors influencing student's pursuit of accounting career in Nigeria Source: Author's compilation, 2020

\section{Methodology}

Three tertiary institutions were randomly selected to represent Private, State and Federal institutions in Nigeria. The selected tertiary institutions are Landmark University, Omu-Aran, Kwara State, Ladoke Akintola University of Technology (LAUTECH), Ogbomoso, Oyo State and University of Ilorin, Ilorin, Kwara State. The population of the study consists of 850 final year undergraduates' regular students (400L) of accounting departments in the selected universities. Sample size of 150 final year students were selected using stratified random sampling. See Table 2

The students were selected for the study because they have been in their various institutions for more than three years, and are conversant with the relevant accounting courses thus; they have explicit comprehension and expectations of their career choices. Furthermore, well-structured questionnaires were distributed to the respondents to obtain essential information. Data was analyzed with frequency distribution and percentages while the stated hypotheses were statistically tested with Spearman's Rank Correlation Co-efficient for hypothesis 1 and 2 respectively

Table 2. Sample size of the respondents

\begin{tabular}{rll}
\hline S/N & Institutions & No of students \\
\hline 1. & University of Ilorin, Ilorin, Kwara State & 50 \\
2. & Ladoke Akintola University, Ogbomoso, Oyo State & 50 \\
3. & Landmark University, Omu-Aran, Kwara State & 50 \\
& Total & 150 \\
\hline
\end{tabular}

Source: Author's computation, 2020

\section{Empirical Results and Discussion}

Cronbach alpha test was conducted and findings in Table 3 showed that the variables have high internal consistency rate. Thus, the data are considered reliable, with the lowest alpha value being 0.73 and the highest being 0.83 . Therefore, the test conducted on factors influencing student's pursuit of professional accounting career in Nigeria is considered valid. 
Table 3. Cronbach's alpha test on the reliability of instruments.

\begin{tabular}{cccc}
\hline Factors & N of items & Cronbach alpha & Reliable items \\
\hline Extrinsic factors & 5 & 0.81 & $81 \%$ \\
Intrinsic factors & 5 & 0.75 & $75 \%$ \\
Prestige factors & 5 & 0.83 & $83 \%$ \\
Social factors & 5 & 0.79 & $79 \%$ \\
Grit Personality & 5 & 0.77 & $77 \%$ \\
Reference factors & 5 & 0.73 & $73 \%$ \\
\hline
\end{tabular}

Source: Author's computation, 2020

\subsection{Descriptive Statistics of Students}

The profiles of the students are presented in Table 4. Findings show that about 56.67 percent of the respondents are females while 43.33 percent are males. This showed that female accounting students are more than their male counterparts. This assertion is in tandem with the submission of Said et al., (2004) that female students are more than male students in institutions of higher learning. Additionally, 60 percent of the respondents asserted that they obtained the information about the professional examination from their lecturers, about 37 percent got information from friends and family members, 27 percent from internet and websites of professional bodies while 17 percent were informed through workshops and accounting seminars which they attended.

Moreover, on responses to future plans after graduation, they were allowed to pick more than one option. Results showed that 47 percent of the students are willing to work immediately after graduation, 30 percent of the respondents are desirous to pursue post graduate studies after graduation, 33 percent would like to get married immediately while 32 percent desire to work towards earning professional certifications. Further findings revealed that only 30 percent of the respondents are interested in obtaining professional certification. 33 percent of the respondents indicate that the possibility of them taking the professional examination may only be probable while 37 percent of the students opined that they aren't interested in pursuing professional qualification. This result clearly shows that majority of the students are not really interested in following the path of professionalism and this may account for the shortage of professional accountants in the country

On the choice of professional programmes, respondents were allowed to pick more than one options and findings showed that if the respondents were to pursue professional qualification, most of them prefer ICAN, followed by ANAN and then ACCA. They have more preference for ICAN because they felt it is recognized both nationally and internationally. 
Table 4. Descriptive Statistics of students

\begin{tabular}{|c|c|c|}
\hline Description & Freq & $\%$ \\
\hline \multicolumn{3}{|l|}{ Gender } \\
\hline Male & 65 & 43.33 \\
\hline Female & 85 & 56.67 \\
\hline Total & 150 & 100 \\
\hline \multicolumn{3}{|l|}{ Plans after graduation } \\
\hline To start work immediately & 70 & 46.67 \\
\hline To further my education & 30 & 20.00 \\
\hline To get married & 50 & 33.33 \\
\hline To pursue professional career & 48 & 32.00 \\
\hline \multicolumn{3}{|l|}{$\begin{array}{l}\text { Choice of professional } \\
\text { programmes }\end{array}$} \\
\hline ICAN & 65 & 43.33 \\
\hline ANAN & 25 & 16.67 \\
\hline ACCA & 10 & 6.67 \\
\hline NONE & 50 & 33.33 \\
\hline Total & 150 & 100 \\
\hline \multicolumn{3}{|l|}{ Pursuit of professional Careers } \\
\hline Certainly & 45 & 30.00 \\
\hline Probably & 50 & 33.33 \\
\hline Unlikely & 55 & 36.67 \\
\hline Total & 150 & 100 \\
\hline \multicolumn{3}{|l|}{$\begin{array}{l}\text { Awareness of professional } \\
\text { programmes }\end{array}$} \\
\hline Lecturers & 90 & 60.00 \\
\hline Workshops and seminars & 25 & 16.67 \\
\hline Internet/ Association's Websites & 40 & 26.67 \\
\hline Friends and family members & 55 & 36.67 \\
\hline Others & 20 & 13.33 \\
\hline
\end{tabular}

Source: Author's computation, 2020

\subsection{Factors Influencing Student's Choice of Accounting Career in Nigeria}

A total of 30 items were chosen from research questionnaires in order to determine the factors influencing student's choice of accounting career. Data was analyzed to find their mean and standard deviation. The analysis from Table 5 on extrinsic factors shows that students have the highest agreement on Item 11 (mean of 4.55) "Professional certification offers higher salary and other financial incentives" and followed by Item 14 (mean of 4.35) "Professional certification offers various job opportunities "This indicates that students may choose accounting as a profession due to its high job opportunity especially during when the competition is tough. This finding is in line with reports of Mustapha \& Abu Hassan (2012) that job stability and security, opportunities for advancement significantly influence students' decision to pursue professional accounting career.

Moreover, analysis for prestige factors showed that students have the highest agreement on item 2 (mean of 4.52) "Professional titles are highly and internationally recognized" and item 1 (mean of 4.45) "Professional accountants 
are more respected than accountants with degree in accounting" This signifies that students are favorably disposed towards accounting career and that being a professional accountant will likely make them to be indispensable. This finding is buttressed with the reports of Ghani \& Said (2009) who found that students perceived status and prestige as motivating factors in the choice of accounting career. Law (2010) also asserted that prestige factor is a driving force that propels students to become professional accountants.

On the contrary, the lowest mean score is item 6 (mean of 2.35) "my parents encouraged me to pursue accounting professional qualification". This report showed that pursuit of accounting career is not usually under any parental influence. This report is supported by the findings of Tan \& Laswad, (2009) and Uyar \&Kuzay, (2011) that family influences do not affect students' pursuit of an accounting career.

Table 5. Factors influencing student's pursuit of professional accounting career

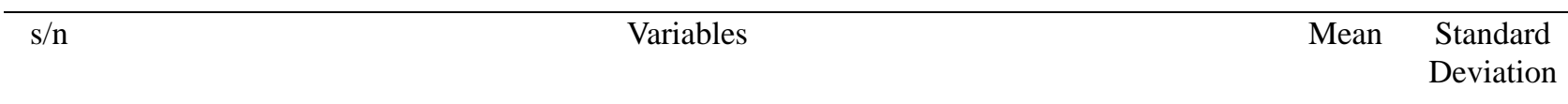

\section{Prestige factors}

1. Accountants with professional qualifications are more respected than accountants with $4.45 \quad 0.59$ degree in accounting

2. Professional titles are highly and internationally recognized

$4.52 \quad 0.50$

3. Being a professional accountant is highly prestigious, influential and enhances one's

$4.35 \quad 0.62$

4. confidence

5. Professional accountants have better opportunity for promotions

$3.85 \quad 0.72$

$4.25 \quad 0.68$

\section{Reference factors}

6. My parents encouraged me to pursue professional qualification $\quad 2.35 \quad 1.12$

7. My performance in school influenced my decision to pursue professional career $\quad 3.58 \quad 0.86$

8. My friends and loved ones encouraged me to pursue professional career $\quad 2.98 \quad 1.02$

9. Successful accountants that have seen or heard about influenced my decision to be a $\quad 2.75 \quad 1.07$ professional accountant

10. My lecturers and academic advisors encouraged me to pursue professional career $\quad 3.95 \quad 0.71$

\section{Extrinsic factors}

11. Professional certification offers higher salary and other financial incentives

$4.55 \quad 0.52$

12. The career of a professional accountant is highly secured

$4.28 \quad 0.63$

13. Work environments for professional accountant is always superb

$4.20 \quad 0.67$

14. Professional certification offers various job opportunities

$4.35 \quad 0.62$

15. Professional certification provides substantial incomes and offers financial security

$4.05 \quad 0.70$

\section{Intrinsic factors}

16. Accounting profession provides better training opportunities

17. Accounting field is very interesting and fun to be around

$3.60 \quad 0.84$

18. Accounting field guarantees bright future opportunities and specialization

$3.85 \quad 0.77$

19. Accounting profession is more flexible compared to other professional job.

$3.66 \quad 0.82$

20. Accounting profession gives a sense of accomplishment

\section{Grit personality}

21. I usually overcome setbacks to conquer an important challenge. $\quad 3.70 \quad 0.81$

22. I usually finish whatever I begin

23. I am highly determined and courageous towards the pursuit of professional exams

3.66

0.85 


\begin{tabular}{lccc} 
24. & I like the challenges when taking professional examination & 2.95 & 1.04 \\
25. & I hope to pass all the professional exam papers in one sitting & 2.80 & 1.08 \\
Social Factors & & \\
26. & Professionalism allows me to contribute immensely to the society & 3.20 & 0.92 \\
27. & Being a certified accountant, I can work well with others & 2.85 & 1.02 \\
28. & Professional Accountants are reputable and well respected in the society & 3.35 & 0.92 \\
29. & Professional accountants are recognized as important in the society & 2.95 & 1.02 \\
30. & Professional accountants interacts with lots of people & 3.22 & 0.90 \\
\hline
\end{tabular}

Source: Authors computation, 2020

\subsection{Relationship between Factors Influencing Student's Career Choice and TheirIntention to Pursue Accounting Career}

Spearman rank correlation was employed to analyze the relationship between factors influencing student's career choice and their pursuit of accounting career as displayed in Table 6. Six factors were considered in the model as determinants, these are grit personality, extrinsic, intrinsic, reference, prestige and social factors. The result of the study showed that strong and positive relationship exist between prestige factor and student's pursuit of professional accounting career $(0.7280, \mathrm{p}<0.05)$. Some respondents suggested that accounting professional certification offers respectable position with authority:

"... I want to be at the helm of affairs. I like to make decision...sign the audit report... I want to be like a partner.... I want to be well respected in the society and stand tall among my peers".

This finding corroborates the assertions of Ghani et al. (2008) and Ghani and Said (2009) that Malaysian accounting undergraduates recognized status and prestige factors as major drivers in choosing accounting as a career path. Similarly, Law (2010) in Hong Kong found that prestige factor is a strong motivator for students to become professionally qualified. Mustapha et al., (2012) revealed that students are eager to become professional accountants because they are highly valued in the society.

Aside this, extrinsic factors also correlated positively and significantly with pursuit of professional qualification $(0.7006, \mathrm{p}<0.05)$. This may be due to the fact that professional qualification increases marketability and offers various job opportunities. Empirical evidence revealed that positive attitudes toward becoming professionally qualified are deeply rooted in extrinsic factors (Germanou \& Hassall, 2009; Mustapha \& Abu Hassan, 2012). One of the respondents clearly emphasized that employment opportunities, financial incentives and good salary motivates her to pursue professional certification.

"I am eager to become professionally qualified.......because of better employment opportunities........and good salary, I must be a professional accountant... and also because I love learning new things in order to gain more knowledge

This result is in tandem with the report of Ghani et al., (2008) that obtaining professional qualifications lead to better employment opportunities, good salary, and prestige. Also, Byrne \& Flood (2005) found that employment opportunity is one of the cogent factors that propel students to become professional accountant.

Moreover, intrinsic factor also showed positive and significant correlation with student's pursuit of professional accounting career $(0.6276, \mathrm{p}<0.05)$. This may be due to the fact that professional qualification guarantees job specialization, offers flexibility and provides job accomplishment. This report is in consonance with the findings of Jakling \& Kenely (2007) and Zakaria, et al., (2012) who asserted that professional qualification provides opportunity for advancement and job experience.

Grit personality also showed moderate and positive correlation with student's pursuit of professional accounting career $(0.5457, \mathrm{p}<0.05)$. The respondents reported that only students that are strong-willed, passionate and determined can pursue professional qualifications effectively. This report tallies with the findings of Bacanli (2006) that personality characteristics influences career indecisiveness. This finding also suggests that the capability to persevere makes completion of professional examinations possible.

In addition to these, positive but weak correlation exists between social factors and pursuit of professional qualification $(0.4182, \mathrm{p}<0.05)$. Also, reference factors exhibited very weak and positive correlation $(0.3592, \mathrm{p}<$ 0.05 ) with pursuit of professional qualification. To buttress this assertion, the findings of Tan and Laswad, (2009) 
showed that family influence does not affect choice of accounting career. Also, Uyar \& Kuzay, (2011) and Byrne, et al., (2012) reported that family and relatives do not significantly affect the choice of accounting as a career. However, findings from this study showed that positive but weak correlation exist between referents and students pursuit of professional accounting career.

Table 6. Relationship between factors influencing student's career choice andstudent's intention to pursue accounting career.

\begin{tabular}{crcccccr}
\hline Factors & Grit & Reference & Extrinsic & Prestige & Intrinsic & Social & Intention \\
\hline Grit & 0.0000 & & & & & & \\
Reference & 0.1174 & 0.0000 & & & & & \\
Extrinsic & 0.1639 & 0.0224 & 0.0000 & & & \\
Prestige & 0.2100 & 0.2271 & 0.7768 & 0.0000 & & \\
Intrinsic & 0.2214 & 0.3422 & 0.7480 & 0.5795 & 0.0000 & & \\
Social & 0.3380 & 0.2915 & 0.3130 & 0.2114 & 0.3608 & 0.0000 & \\
Intention & 0.5457 & 0.3592 & 0.7006 & 0.7280 & 0.6276 & 0.4182 & 0.0000 \\
\hline
\end{tabular}

Correlation is significant at 0.01 level (2 tailed)

Source: Author's computation, 2020

\subsection{Perception of Accounting Students towards Professional Examinations in Nigeria}

Table 7 shows item-by-item percentage analysis of the Students Self- Rating Attitudinal Inventory (SSAI) that was administered on the respondents. Findings showed that most of the students (83.33 percent) perceived that professional examinations are very tough and difficult, thus they may need to make several attempts to pass the examinations. This assertion is buttressed with the reports of Omar (2009) and Ossisioma (2001) that it is very easy for a camel to pass through the eye of a needle than for a young Nigerian to excel in accounting professional examination.

Moreover, almost all the students (96.67 percent) asserted that professional examinations require considerable time and efforts. They felt professional examinations require rigorous reading and higher hours of workload. Also, 85.33 percent of the students are of the view that professional examinations are very expensive. Students opined that application, registration, and exam fees cost so much. More so, professional bodies have no coaching centers to prepare students ahead for these examinations therefore; they have no option but to register with private coaching centers that charge exorbitantly.

Furthermore, some students are also of the opinion that their curriculum is unattractive, fully loaded and filled with unnecessary topics. All these and many more are responsible for the negative perception that accounting students have towards professional examinations in Nigeria. 
Table 7. Perception of accounting students towards professional examinations in Nigeria

\begin{tabular}{ccccc}
\hline $\mathrm{s} / \mathrm{n}$ & Reasons & & & \\
& & Agree $(\%)$ & Disagree (\%) & Can’t say (\%) \\
\hline $\mathbf{1}$ & Professional examinations are tough and very difficult to pass & $125(83.33)$ & $10(6.67)$ & $15(10.00)$ \\
$\mathbf{2}$ & Professional examinations require time and effort & $145(96.67)$ & $2(1.33)$ & $3(2.00)$ \\
$\mathbf{3}$ & Professional certification does not necessarily reflect my ability & $55(36.67)$ & $50(33.33)$ & $45(30.00)$ \\
$\mathbf{4}$ & Professional certification is very expensive & $128(85.33)$ & $12(8.00)$ & $10(6.67)$ \\
$\mathbf{5}$ & Being a certified accountant does not necessarily guarantee job provision & $25(16.67)$ & $80(53.33)$ & $45(30.00)$ \\
$\mathbf{6}$ & Aside professional examinations, additional skills are still needed & $45(30.00)$ & $45(30.00)$ & $60(40.00)$ \\
$\mathbf{7}$ & Their curriculum is unattractive and fully loaded & $90(60.00)$ & $30(20.00)$ & $30(20.00)$ \\
$\mathbf{8}$ & Postgraduate study in MBA, M.Sc/PhD Accounting is preferable to & $50(33.33)$ & $35(23.33)$ & $65(43.34)$ \\
$\mathbf{9}$ & professional qualification & & & $45(30.00)$ \\
$\mathbf{1 0}$ & Many registered students are unable to complete the programme & $80(53.33)$ & $25(16.67)$ & $45)$ \\
\hline
\end{tabular}

4.5 Summary of Findings

i. Grit personality, prestige, extrinsic and intrinsic factors exhibited strong and positive correlation with student's intention to pursue accounting career.

ii. Students intend to pursue accounting career because professionalism offers high salary, provides job opportunities and brings prestige, respect and recognition both locally and internationally.

iii. However, students perceive professional examinations to be very expensive, tough and require considerable time and efforts

\section{Conclusion}

Findings indicated that good salary, financial incentives, recognition, prestige as well as opportunities for career advancement influence student's choice of accounting career in Nigeria. This study revealed that grit personality, prestige, extrinsic and intrinsic factors are significant forces that assist students in the pursuit of professional accounting career. Based on these findings, it is highly essential for lecturers and educators to focus on educational aspiration build personal characteristics in motivating students and stress the importance of professional accounting education in relation to intended accounting career.

Furthermore, findings indicated that that grit personality, prestige, extrinsic and intrinsic factors exhibited strong and positive correlation with student's pursuit of accounting career. However, social and reference factors displayed positive but weak correlation. Additionally, students perceive professional examinations to be very tough, expensive, time-consuming and frightening. Thus, they refrain from writing professional examinations and this could be detrimental to the future of accounting career in Nigeria.

\subsection{Limitation}

This study is limited by the small sample size as it only considered the graduating (400 level) accounting students of the three selected universities in Nigeria. Future research should be conducted on a larger sample. However, the research contributes to existing literature by providing information to Nigerian universities and professional bodies on the factors that motivates students in their pursuit of professional career. Also, findings of this study can assist professional bodies in mapping out strategies to attract outstanding students in order to produce graduates that are exceptionally talented. Other than accomplishing the country's motive of increasing the number of professional accountants, this study will also enhance the future viability of professional bodies.

\section{References}

Albrecht, W. S., \& Sack R. J. (2000). "Accounting education: charting the course through a perilous future," Accounting Education Series, Vol. No. 16, American Accounting Association, Sarasota, FL.

Arquero, J. L., Byrne, M., Flood, B., \& Gonzalez, J. M. (2009). Motives, expectations, preparedness and academic performance: A study of students of Accounting at a Spanish University. Revista de Contabilidad, 12(2), 279-299. https://doi.org/10.1016/S1138-4891(09)70009-3 
Bacanli, F. (2006). Personality characteristics as predictors of personal indecisiveness. Journal of CareerDevelopment, 32(4), 320-332. https://doi.org/10.1177/0894845305282941

Byrne \& Willis P (2005). "Irish secondary students' perceptions of the work of an accountant and the accounting profession," Accounting Education, I4(4), 367-381. https://doi.org/10.1080/06939280500346003

Byrne, M., \& Flood, B. (2005). "A study of accounting students' motives, expectations and preparedness for highereducation," Journal of Further and Higher Education, 29(2), 111-124.https://doi.org/10.1080/03098770500103176

Byrne, M., Flood, B., Hassall, T., Joyce, J., Montano, J. L. A., Gonzalez, J. M. G., \& Tourna-Germanou, E. (2012). Motivations, expectations, and preparedness for higher education: A study of accounting students in Ireland, the UK, Spain, and Greece. Accounting Forum, 36, 134-144. https://doi.org/10.1016/j.accfor.2011.12.001

Chen, C., Jones, K., \& Mcintyre, D. D. (2008). "Analyzing the Factors Relevant to Students' Estimations of theBenefits and Costs of Pursuing an Accounting Career." Accounting Education, 17, 3, 313-326. https://doi.org/10.1080/09639280701788703

Coate, C. J., Mitshow, M. C., \& Schinski, M. D. (2003). "What students think of CPAs: Is the stereotype alive and well?" CPA Journal, 3(8), 52-56.

Dalci, I., Arasli, H., Tümer, M., \&Baradarani, S. (2013). Factors that influence Iranian students' decision tochoose accounting major. Journal of Accounting in Emerging Economies, 3(2), 145-163. https://doi.org/10.1108/20421161311288866

Duckworth, A. L., \& Peterson, C. (2007). Grit: Perseverance and passion for long-term goals. Journal of Personality and Social Psychology, 92, 1087-1101. https://doi.org/10.1037/0022-3514.92.6.1087

Emenvonu, E. N. (2007). Emerging trends and technologies in accounting - a Nigerian Perspective. Paper presented by Professor and Head, Department of Accounting, Southern Connecticut State university, New Haven, Connecticut Visiting Professor Covenant University, Ota, Ogun State, Nigeria at University of Benin, Benin City, Nigeria on August, 17.

Germanou, E., \& Hassall, T (2009). Students' perceptions of accounting profession: work value approach, AsianReview of Accounting, 17(2), 136-148. https://doi.org/10.1108/13217340910975279

Germanou, E., Hassall, T., \& Tournas, Y. (2009). Students' perceptions of accounting profession: Work value approach. Asian Review of Accounting, 17(2), 136-148. https://doi.org/10.1108/13217340910975279

Ghani, E. K., Said, J., Nasir, N. M., \& Jusoff, K. (2008). The 21st Century Accounting Career from the Perspective of the Malaysian Universities Students, Asian Social Science, 4(8), 73-83. https://doi.org/10.5539/ass.v4n8p73

Gujarati, D. N. (2003). Basic econometrics (4th ed.). Singapore: McGraw Hill.

Gunkel, M., Schlaegel, C., Langella, I. M., \& Peluchette, J. V. (2010). Personality and career decisiveness. Personnel Review, 39, 503-524. https://doi.org/10.1108/00483481011045443

Hardin, J. R., O’Bryan, D., \& Quirin, J. J. (2000). Accounting versus engineering, law, and medicine: Perceptions of influential high school teachers. Advances in Accounting, 17, 205-220. https://doi.org/10.1016/S0882-6110(00)17012-9

Hartwell, C. L., Lightle, S. S., \& Maxwell, B. (2005). "High School Students' Perceptions of Accounting." The CPA Journal, January, 62-67.

Hunt, S. C., Anthony, F. A., \& Intrieri, R. C. (2004). The nature and origins of students' perceptions of accountants. Journal of Education for Business, 79(3), 142-149. https://doi.org/10.3200/JOEB.79.3.142-148

Jackling B., \& Keneley M. (2007). "Influences on the potential supply of and demand for accounting graduates: a focus on the impact of international enrollments in tertiary accounting courses in Australia". Paper presented at AFAANZ Conference, July, Gold Coast.

Jackling, B., \& Calero, C. (2006). Influences on Undergraduate Students' Intentions to become qualified Accountants: Evidence from Australia. Accounting Education: An International Journal, 15(4), 419-438 https://doi.org/10.1080/09639280601011115

Jackling, B., de Lange, P., Phillips, J., \& Sewell, J. (2012). Attitudes towards accounting: differences between Australian and international students. Accounting Research Journal, 25, 113-130 https://doi.org/10.1108/10309611211287305 
Johnson, G. (2003). Computerized CPA exam only months away. Journal of Accountancy, (September), 11-12.

L. M. Tan \& F. Laswad (2006). "Students' beliefs, attitudes and intentions to major in accounting," Accounting Education: An International Journal, 15(2), 167-187. https://doi.org/10.1080/09639280600787194

Lanson, J. (2010). Malaysia needs 60,000 accountants. Utusan Malaysia. Retrieved on August 10, 2010 from http://www.utusan.com.my/utusan /info.asp

Law, P. K. (2010). A Theory of reasoned action model of accounting students' career choice in public accounting practices in the post-Enron. Journal of Applied Accounting Research, 11(1), 58-73. https://doi.org/10.1108/09675421011050036

Marriott, P., \& Marriott, N. (2003). "Are we turning them on? A longitudinal study of undergraduate accounting students' attitudes towards accounting as a profession." Accounting Education, 12(2), 113-133. https://doi.org/10.1080/0963928032000091738

Mauldin, S., Crain, J. L., \& Mounce, P. H. (2000). The accounting principles instructor's influence on student's decision to major in accounting. Journal of Education for Business, 75(3), 142-148. https://doi.org/10.1080/08832320009599005

Mustapha, M., \& Abu Hassan, M. H. (2012). Accounting Student's Perception on Pursuing Professional Examination. International Journal of Accounting, 4(4), 1-15. https://doi.org/10.5296/ije.v4i4.1546

Omar, N. (2009). Factors influencing the diploma in accounting (DIA) students 'decision to pursue professional accounting programmmes. Master's thesis submitted to the College of Business, Universiti Utara Malaysia.

Ossisioma, B. C. (2001). The Accountancy profession in Nigeria: Yesterday, Today and Tomorrow Being a paper delivered at Educational Development \& Production of Accountants in Nigeria: Challenges \& Way Forward the Association of National Accountants of Nigeria, Edo Branch Week Programme held at Saidi Centre, Benin-City. Jan. 22-25.

Parker, L. (2000). Goodbye, Number Cruncher! Australian CPA, 70(2), 50-52. ISSN: $1440 \quad-8880$ http://hdl.handle.net/2440/33485

Pimpa, N. (2007). The influence of normative referents on Thai students' choice of international education [online] Monash Centre for Research in International Education. http://www.aare.edu.au/01pap/pim01016.html

Said, J., Ghani, E. K., Hashim, A., \& Nasir, N. M. (2004). Perception Towards Accounting Career Among Malaysian Undergraduates. Journal of Financial Reporting and Accounting, 2(1), 17-30 https://doi.org/10.1108/19852510480000658

Snyder, A. (2004). Tips on preparing employees for the new CPA exam. Journal of Accountancy, (March), 11-12.

Sugahara, S., \& Boland, G. (2006). Perceptions of the certified public accountants by accounting and non-accounting tertiary students in Japan. Asian Review of Accounting, 14(1/2), 149-167. https://doi.org/10.1108/13217340610729518

Tan, Lin Mei \& Laswad, Fawzi. (2009). "Understanding Students' Choice of Academic Majors: A LongitudinalAnalysis", Accounting Education, 18: 3, 233-253. https://doi.org/10.1080/09639280802009108

Uyar\&Kuzey. (2011). "Factors Affecting Students' Career Choice in Accounting: The Case of a Turkish University", American Journal of Business Education; Oct 2011, Vol. 4 Issue 10, p29 20. https://doi.org/10.19030/ajbe.v4i10.6061

Wells, P. K., \& Fieger, P. (2005). Accounting: Perceptions of influential high school teachers in the USA and NZ. Chicago Research paper Series. ISSN Number 1176-1997.

Wessels, P. L., \& Steenkamp, L. P. (2009). An investigation into students' perceptions of accountants. Meditari Accountancy Research, 17(1), 117-132. https://doi.org/10.1108/10222529200900008.

Zakaria, M., Wan Fauzi W. A., \& Hasan S. J. (2012). “Accounting as a Choice of Academic Program”, Journal of Business Administration Research Vol. 1, No. 1, 43-56. https://doi.org/10.5430/jbar.v1n1p43

\section{Copyrights}

Copyright for this article is retained by the author(s), with first publication rights granted to the journal.

This is an open-access article distributed under the terms and conditions of the Creative Commons Attribution license (http://creativecommons.org/licenses/by/4.0/). 